\title{
ЕКОНОМІЧНА ПОЛІТИКА
}

\author{
УДК 330.3"20" DOI: https://doi.org/10.31617/zt.knute.2019(105)03 \\ яСько Юлія к. е. н., ст. викладач кафедри економічної теорії \\ та конкурентної політики Київського національного \\ E-mail: u.yasko@knute.edu.ua \\ торговельно-економічного університету \\ вул. Kiото, 19, м. Київ, 02156, Україна
}

\section{ЕКОНОМIКА XXI CT.: ТРАНСФОРМАЦІЯ РОЛІ ДЕРЖАВИ}

Досліджено основні теоретичні підходи до аналізу ролі держави в економіиі. Розглянуто сучасні проблеми взаємозв'язку державного та ринкового регулювання економіки. Проаналізовано вилив ефективного державного втручання в економіку на їі конкурентоспроможність. Доведено необхідність трансформації ролі держави в економіиі в сучасних умовах господарювання.

Ключові слова: держава, державне регулювання економіки, ринкове саморегулювання, глобалізація, конкурентоспроможність.

Ясько Ю. Экономика ХХІ в.: трансформация роли государства. Исследованы основные теоретические подходы к анализу роли государства в экономике. Рассмотрены современные проблемы взаимосвязи государственного и рыночного регулирования экономики. Проанализировано влияние эффективного государственного вмешательства в экономику на ее конкурентоспособность. Доказана необходимость трансформачии роли государства в экономике в современных условиях хозяйствования.

Ключевые слова: государство, государственное регулирование экономики, рыночное саморегулирование, глобализация, конкурентоспособность.

Постановка проблеми. Фундаментальні трансформації, що відбуваються у світі на початку XXI ст. і супроводжуються глобальною фінансово-економічною кризою, вимагають впровадження системних змін у нове економічне і соціальне середовище. Насамперед, це стосується переосмислення ролі держави та ії функцій в економіці. Основною властивістю останніх десятиліть є активний розвиток глобалізаційних процесів, а тому неможливо залишити без уваги їх вплив на державу та ефективність державного регулювання. Останнім часом у науковій літературі зазначена проблематика досить часто розглядається 3 двох

(С) Ясько Ю., 2019 
полярно протилежних точок зору - від повного «відмирання» інституту держави в економіці до активного державного втручання в соціальноекономічний розвиток. Проте за умов глобалізації поділ економічних систем на ринкову й адміністративно-регульовану не є доцільним, так як в ідеальному вигляді жодної з них вже не існує. Тому в цьому дослідженні розглянуто питання трансформації ролі держави в економіці під впливом новітніх системних викликів.

Аналіз останніх досліджень і публікацій. Різноманітні аспекти трансформації ролі держави в економіці вивчалися як іноземними, так і вітчизняними науковцями. Вагомий внесок у дослідження зазначеної проблематики здійснили: Д. Аджемоглу, Дж. Акерлоф, В. Геєць, А. Гриценко, Я. Жаліло, Ю. Кіндзерський, В. Лагутін, А. Мазаракі, Е. де Сото, Ю. Уманців [1-10] та ін.

Проте серед численних наукових здобутків з цього питання донині відсутній єдиний підхід до визначення меж державного втручання в економічні процеси, що вимагає пошуку модернізованих методів та інструментів державного регулювання економіки, враховуючи сучасні тенденції.

Метою статті $є$ дослідження теоретико-методологічних засад трансформації ролі держави в економіці під впливом новітніх системних викликів.

Матеріали та методи. Під час дослідження використано такі загальнонаукові та спеціальні методи, як: історико-логічний - для вивчення еволюції ролі держави на різних етапах господарського розвитку; системний підхід - для дослідження теоретичних аспектів та сучасних засад державного регулювання економіки; ретроспективного та порівняльного аналізу - під час розгляду впливу ефективного державного управління на конкурентоспроможність національної економіки; аналізу та синтезу - для визначення взаємозв'язків між державним та ринковим регулюванням економіки.

Результати дослідження. Побудова соціально орієнтованої економіки та демократичного суспільства на основі інноваційної моделі розвитку обумовлює необхідність нагального вирішення завдання щодо визначення нової ролі держави, що, у свою чергу, є неможливим без відповідного теоретичного підгрунтя.

Ключовим інститутом сучасної економіки є держава. Вона не повинна прямо втручатися в господарські процеси. Проте до її функцій належить створення такого інституційного середовища, яке здатне забезпечити ефективне функціонування господарського механізму, що стимулює інноваційний розвиток та надання державної підтримки галузям, що стратегічно важливо для економічного розвитку та конкурентоспроможності національної економіки.

Проблема державного втручання в економіку має багаторічну історію. Починаючи з кінця XV ст., науковці почали досліджувати проблематику необхідності та міри державного регулювання економіки. У процесі розвитку економічної думки ставлення до ролі держави 
постійно змінювалося. До XVII ст. переважала думка про те, що держава повинна відігравати активну роль у розвитку торгівлі та промисловості. Опонував цьому твердженню А. Сміт, який у своїй праці «Дослідження про природу й причину багатства народів» (1776 р.) наголошував на обмеженій ролі держави в економічному розвитку країни. Вчений дотримувався принципу ринкової рівноваги, яка досягається в економіці стихійно, за відсутності державного втручання, і $є$ оптимальним варіантом функціонування економічної системи. Тому, на думку А. Сміта, держава не повинна втручатися в регулювання економічних процесів, а повинна лише здійснювати первинні функції, необхідні для функціонування ринку [11, с. 236].

Дж. С. Мілль присвятив декілька розділів своєї книги «Основи політичної економії», опублікованої в 1948 р., питанню впливу держави на економічні процеси. Ключова ідея вченого полягала в тому, що ринок є саморегулюючим інститутом, і держава не повинна втручатися у діяльність суб'єктів господарювання, а основним чинником у встановленні макроекономічної рівноваги є вільна конкуренція [12, с. 394]. Уже $з$ того часу вчені почали досліджувати окремі аспекти економічних функцій держави та межі ії втручання в економіку.

У сучасній економічний науці відбулося утвердження теорій, розроблених трьома провідними економічними школами, а саме: кейнсіанською, неокласичною та інституціональною, які відрізняються за своєю суттю.

Технологічні зміни, які відбулися в ХХ ст., внесли суттєві корективи в уявлення про механізм ринкового саморегулювання. Велика депресія 30-х років XX ст. висунула перед економістами нову проблему, вирішенню якої і присвячена кейнсіанська теорія. Це привело до переосмислення традиційних поглядів на роль держави в економіці. Стало зрозумілим, що держава повинна активно втручатися в економіку, оскільки вільний ринок не мав механізмів впливу на процес виходу економіки з кризи.

Фундатором теорії державного регулювання економіки вважається Дж. Кейнс. У своїй основній науковій праці «Загальна теорія зайнятості, проценту і грошей» учений довів, що держава має відігравати ключову роль та активно втручатися в економічні процеси [13].

На відміну від Дж. Кейнса, представники неокласичної економічної теорії віддавали перевагу ринковому механізму саморегулювання економіки, що обмежує міру державного втручання в економіку. Наприклад, А. Маршалл схвалював переваги вільно конкурентної структури ринку, що розпочав А. Сміт. У своїх наукових дослідженнях учений дійшов висновку, що втручання держави можливе, але воно повинно бути мінімальним, інакше в економіці виникатимуть диспропорції [14, с. 297].

Окремі положення щодо обмеження регулювання процесів економічного розвитку з боку держави передбачали й розробки представників інституціональної теорії. Вихідні засади інституційного підходу набувають особливого значення для країн з перехідною економікою, 
оскільки розглядають економіку не як статичну систему, а як живий організм, що постійно модифікується. Так, Дж. К. Гелбрейт відводив державі значну роль в економіці. На його думку, ключову роль у системі регулювання економіки відіграють державні видатки, які є генеруючим чинником, що регулює сукупний попит та ціни [15, с. 261].

У свою чергу, представники неокласичного синтезу наполягали на взаємодії державного регулювання з функціонуванням ринкових механізмів, що давало надію на вдосконалення інструментів регулювання економіки взагалі.

Дослідивши різнобічні підходи до ролі держави в економіці на різних етапах господарського розвитку, встановлено, що необхідність виконання державою окремих функцій в економіці не заперечує ніхто. Проте існує велика розбіжність у поглядах стосовно меж та напрямів державного втручання в економіку - від суто ліберального до повного державного регулювання економічних процесів.

Однак у XXI ст., зважаючи на стрімкий розвиток глобалізаційних процесів, втручання держави в економічні процеси повинно бути не тільки більш активним, але й стабільним та послідовним. При цьому його зміст не може визначатися лише ідеологічними засадами та принципами, повинні також враховуватися новітні тенденції суспільного розвитку.

Сучасна економіка 3 точки зору іiі глобалізації розглядається як синтез ринкового механізму та елементів державного регулювання, які постійно модифікуються під впливом розвитку світових господарських зв'язків і суспільства. Така модель закладена історично, адже «чистої», нерегульованої економіки не існує, тому що об'єктивним є процес боротьби економічних суб'єктів за ресурси, товари й ринки. Об'єктивна реальність розвитку господарського механізму в ринковій економіці вимагає регулювання, так як нерегульований ринок не може бути ефективним - цей постулат доведений часом.

На реалізації проактивної державної прагматичної економічної політики наполягає Б. Данилишин, який зазначає, що будь-яка економічна політика, як на Заході, так i на Сході, $є$ складним міксом кейнсіанських, монетаристських та інших заходів. Ніхто з економістівпрактиків у світі не може сьогодні назвати себе ні чистим кейнсіанцем, ні монетаристом [16].

Схожих принципів дотримується В. Панченко, який стверджує, що необхідно вийти за межі діалектики «лібералізм-протекціонізм», «держава-ринок». Старі протекціоністські інструменти відходять у минуле, нині з'являються нові форми. Недарма в європейській практиці набуває вжитку термін «reregulation», що пояснює стан, коли дерегуляція, передбачаючи зняття обмежень, концентрується на запровадженні нових форм регуляції [17].

Здійснення економічної політики держави потребує виходу на таку інституційну траєкторію, яка здатна забезпечити поступовий перехід до моделі, орієнтованої одночасно і на розвиток конкуренції, і на 
подолання обмежень ринку на основі цілеспрямованого формування відносин співпраці між державою, підприємницьким сектором та суспільством у цілому. Необхідність економічної політики держави обумовлена передусім існуванням «неспроможності ринку» та потребою державного втручання у розвиток макроекономічних процесів [10, с. 145].

Таким чином, у XXI ст. не лише повинна бути посилена роль держави, але й необхідним є перегляд iї економічних функцій для досягнення стратегічних цілей, які стають все більше спрямованими на побудову соціально орієнтованої економіки та враховують глобалізаційні виклики. 3 огляду на це, розроблено орієнтовану систему трансформації економічних функцій держави в сучасних умовах (рисунок).

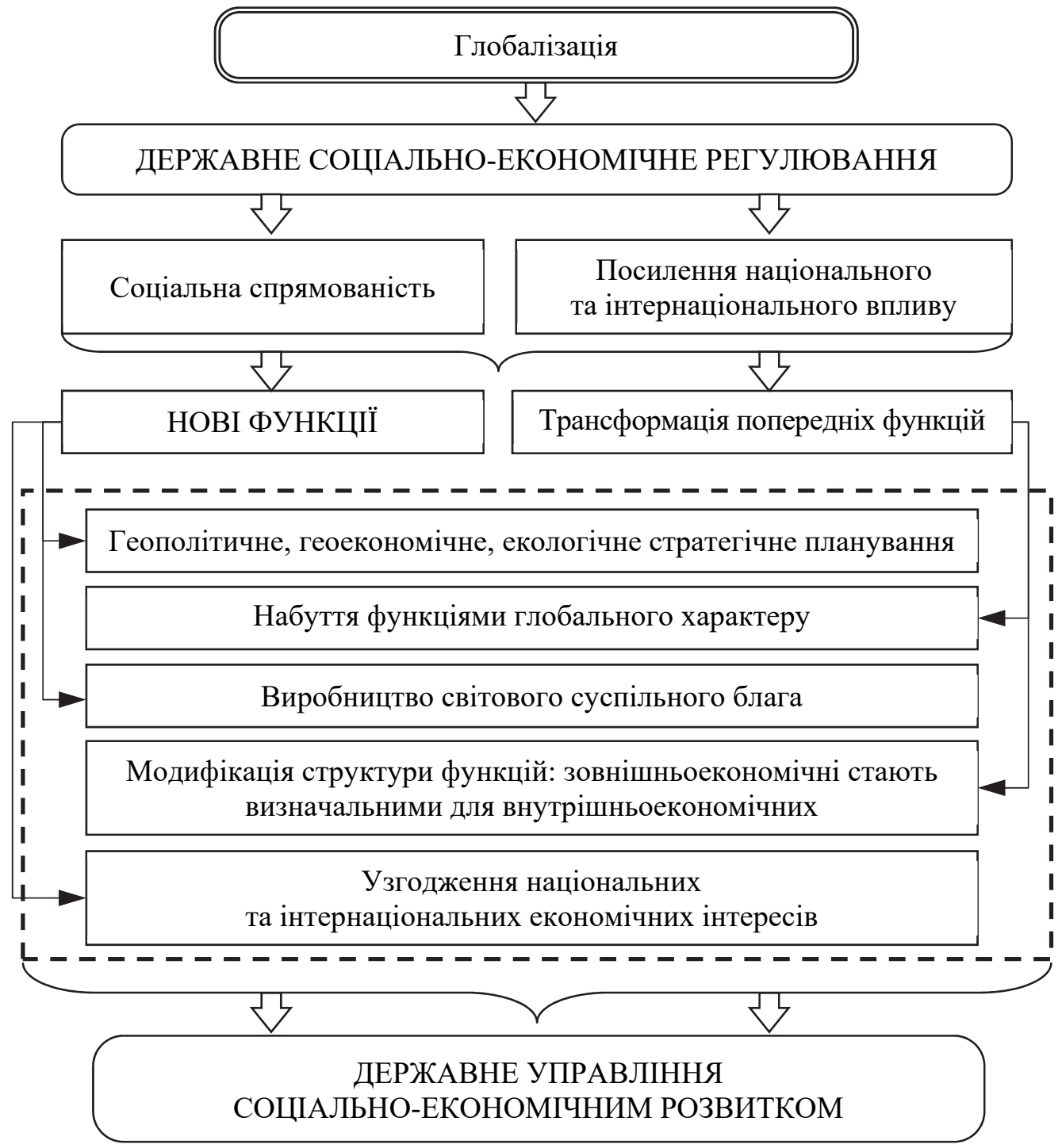

Трансформація економічних функцій держави

Джерело: авторська розробка. 
Стратегічною метою державного регулювання є забезпечення ефективності функціонування національної економіки. I тут важливо те, як державне регулювання впливає на конкурентоспроможність національної економіки, яка, в свою чергу, є важливим індикатором економічного розвитку держави.

Щодо оцінки ефективності впливу держави на економіку з точки зору іiі конкурентоспроможності, то тут існує така закономірність: без ефективного та виваженого державного втручання високої конкурентоспроможності національної економіки на світовому ринку досягти неможливо, а отже, державне управління $є$ фактором конкурентоспроможності.

Як приклад, проаналізуємо дані рейтингів конкурентоспроможності країн Міжнародного Інституту Розвитку Управління (IMD). Фахівці Інституту щорічно розраховують індекси глобальної конкурентоспроможності країн (World Competitiveness Yearbook). Відповідно до методики Лозанського Інституту на конкурентоспроможність національної економіки впливають чотири групи агрегованих факторів: стан економіки; ефективність державного управління; стан бізнес-середовища та інфраструктури. У цьому рейтингу для оцінки ефективності державного управління в контексті конкурентоспроможності використовуються такі підфактори: державні фінанси; фіскальна політика; державні інститути; законодавче регулювання підприємництва та освіта.

На основі даних Лозанського рейтингу конкурентоспроможності країн проаналізуємо вплив фактора ефективності державного управління на загальний рейтинг глобальної конкурентоспроможності (табл. 1, 2).

Таблиия 1

Рейтинг країн за фактором ефективності державного управління Глобальної конкурентоспроможності (окремі країни) у 2019 р. [18]

\begin{tabular}{|l|c|}
\hline \multicolumn{1}{|c|}{ Країна } & Рейтинг \\
\hline Гонконг & 1 \\
\hline ОАЕ & 2 \\
\hline Сінгапур & 3 \\
\hline Швейцарія & 4 \\
\hline Катар & 5 \\
\hline Данія & 6 \\
\hline Норвегія & 7 \\
\hline Німеччина & 8 \\
\hline Нідерланди & 9 \\
\hline Люксембург & 10 \\
\hline США & 23 \\
\hline
\end{tabular}


Рейтинг Глобальної конкурентоспроможності (окремі країни) y 2018-2019 pp. [18]

\begin{tabular}{|l|c|l|c|}
\hline \multicolumn{1}{|c|}{ Країна } & Рейтинг 2019 & \multicolumn{1}{c|}{ Країна } & Рейтинг 2018 \\
\hline Сінгапур & 1 & США & 1 \\
\hline Гонконг & 2 & Гонконг & 3 \\
\hline США & 3 & Сінгапур & 4 \\
\hline Швейцарія & 4 & Нідерланди & 5 \\
\hline ОАЕ & 5 & Швейцарія & 7 \\
\hline Нідерланди & 6 & Данія & 8 \\
\hline Ірландія & 7 & ОАЕ & 9 \\
\hline Данія & 8 & Норвегія & 10 \\
\hline Швеція & 9 & Швеція & 59 \\
\hline Катар & 10 & Канада & 63 \\
\hline Україна & 54 & Україна & \\
\hline Венесуела & 63 & Венесуела & \\
\hline
\end{tabular}

Так, у рейтингу за 2019 р. Гонконг, ОАЕ, Сінгапур та Швейцарія за фактором «ефективність державного управління» посіли чотири перші місця, а в загальному рейтингу Глобальної конкурентоспроможності розмістились відповідно на 2, 5, 1 та 4 місцях. Україна в загальному рейтингу 2019 р. посіла 54 місце 363 країн. Найбільш конкурентоспроможною країною у 2019 р. став Сінгапур, посівши 1 місце в цьому рейтингу. Отже, ті країни, які в 2019 р. за фактором «ефективність державного управління» посіли перші чотири позиції, увійшли до першої п'ятірки загального рейтингу Глобальної конкурентоспроможності, винятком стали лише США, які, незважаючи на 23 позицію в рейтингу за фактором «ефективність державного управління», у загальному рейтингу посіли 3 місце.

3 огляду на це, можна прослідкувати певну взаємозалежність між якістю й ефективністю державного управління та конкурентоспроможністю економіки. Країни з високим рівнем ефективності державного управління займають високі позиції у рейтингу конкурентоспроможності. А тому ефективність державного управління є одним з ключових факторів стійкості та конкурентоспроможності національної економіки.

Не можна не погодитися з твердженням, що у XXI ст. конкурентоспроможними будуть держави, здатні скористатися власним історичним досвідом і використати найкращі характеристики інших моделей для мобілізації ресурсів за допомогою ефективної системи стратегічного планування, налагодження механізмів взаємодії з громадянським суспільством та інвестування в соціальні програми [19, с. 15].

Звернувшись до досвіду найбільш розвинених країн світу, можна спостерігати тенденцію, що зазначені країни, всупереч ліберальному підходу до ролі держави в економіці, не тільки не знижують цю роль, але і значно підвищують, особливо у визначенні пріоритетів розвитку і диверсифікації економік у бік високотехнологічних галузей виробництва. 
Держава як головний інститут суспільства може i повинна бути основним ініціатором інновацій, координатором і гарантом здійснення геоекономічних цілей.

Висновки. Результати аналізу сучасних тенденцій трансформаційних процесів свідчать, що для ефективного розвитку національної економіки в XXI ст. посилення ролі держави в економіці не повинно розумітися як встановлення бюрократичних перепон для підприємництва. Держава, коригуючи колишні помилки економічної політики, більшою мірою має брати на себе властиві їй функції захисту національної економіки від негативних впливів глобалізації, стимулювання інноваційного розвитку, посилення соціальної спрямованості, забезпечення раціонального з розрахунком на майбутне, використання ресурсів.

За підсумками аналізу наукової літератури виявлено відсутність єдиної точки зору на роль та межі втручання держави в економіку. Досліджуючи проблему співвідношення державного втручання в економіку та ринкового саморегулювання, виявлено, що раціональне державне регулювання економіки не суперечить ринковому механізму, а свідомо використовує його регулюючий потенціал, що, в свою чергу, надає ринковим регуляторам можливість більш ефективно та цілеспрямовано впливати на соціально-економічний розвиток. У результаті це повинно сприяти досягненню цілей і пріоритетів, які визначила держава, мінімізуючи при цьому економічні та соціальні втрати.

\section{СПИСОК ВИКОРИСТАНИХ ДЖЕРЕ $Д$}

1. Аджемоглу Д., Робінсон Дж. Чому нації занепадають. Київ: Наш формат, 2017. $440 \mathrm{c}$.

2. Акерлоф Дж., Шиллер Р. Хто і як маніпулює вашим вибором; пер. 3 англ. О. Герасимчук. Київ: Наш формат, 2017. 272 с.

3. Геєць В. Подолання квазіринковості - шлях до інвестиційно орієнтованої моделі економічного зростання. Економіка Украӥни. 2015. № 6. С. 4-17.

4. Гриценко А. Архітектоніка економічної безпеки: монографія. Київ: НАН України, Ін-т економіки та прогнозування НАН України, 2017. 224 с.

5. Жаліло Я. Про національні особливості економічного прагматизму. Дзеркало тижня. 2016. № 49.

6. Кіндзерський Ю. Державне замовлення у світі та особливості його застосування у політиці розвитку: уроки для України. Економіка України. 2015. № 3. С. 4-25.

7. Лагутін В. Економічна політика держави та ефекти їі реалізації. Вісник Київ. наи. торг.-екон. ун-ту. 2017. № 4. С. 5-20.

8. Mazaraki A., Melnichenko S., Duginets G. Ukrainian economy growth imperatives. Prague: Coretex CZ SE, 2018. $310 \mathrm{p}$.

9. Сото де Е. Загадка капіталу. Чому капіталізм перемагає на Заході і ніде більше. Київ: Наш формат, 2017. 332 с.

10. Уманців Ю., Міняйло О. Еволюція ролі та функцій держави в економіці. Економічний вісник університету. 2016. Вип. 28 (1). С. 140-148.

11. Сміт А. Добробут націй. Дослідження про природу та причини добробуту націй; пер. $з$ англ. О. Васильєва. Київ: Port-Royal, 2001.

12. Милль Дж. С. Основы политической экономии; пер. с англ.; общ. ред. А. Г. Милейковского. в 2-х т. М.: Прогресс, 1980. Т. 1. 560 с.

13. Кейнс Дж. М. Общая теория занятости, процента и денег; пер. с англ. Н. Н. Любимова. М.: Гелиос АРВ, 2011. 
14. Маршалл А. Принципы экономической науки: в 3-х т. М.: Бизнеском, 2010.

15. Гэлбрейт Дж. К. Новое индустриальное общество. Избранное. М.: Эксмо, 2008. $1200 \mathrm{c}$.

16. Данилишин Б. Про тактику економічного розвитку. Лівий берег. 2016. 16 грудня. URL: http://blogs.lb.ua/bogdan_danylysyn/353627.

17. Панченко В. Операція «деіндустріалізація», або навіщо нам промисловий ренесанс. Дзеркало тижня. 2016. № 9.

18. The World Competitiveness Yearbook 2019. International Institute for Management Development. Lausanne, Switzerland. URL: https://www.imd.org/wcc/products/eshopworld-competitiveness-yearbook.

19. Артьомова Т. Відносини суспільного відтворення в Україні у контексті трансформації моделей державного управління. Економічна теорія. 2016. № 3. С. 5-17.

Стаття надійшла до редакиії 01.07.2019.

Yasko Yu. The economy in the XXI century: transformation of the state's role.

Background. The main feature of recent decades is the active development of globalization processes, and therefore it is impossible to ignore their influence on the transformation of the role of the state and the effectiveness of state regulation. The construction of a socially oriented economy and a democratic society, based on the innovative model of development, necessitates the urgent solution of the task of determining the new role of the state, which in turn is impossible without the search of the appropriate theoretical basis.

The analysis of recent researches and publications shows that despite the existence of certain scientific achievements, there is still no single point of view regarding the role of the state in the economy. Until now, the boundaries and the relationship between state and market regulation have not been clearly and comprehensively defined.

The aim of the article is to study theoretical and methodological principles of the transformation of the role of the state in the economy under the influence of the latest systemic challenges.

Materials and methods. In the process of research the general scientific and special methods were used, such as: historical and logical; method of retrospective and comparative analysis; system approach; analysis and synthesis.

Results. The key institution of the modern economy is the state. It should not directly interfere in business processes. However, its functions include the creation of such an institutional environment that is capable of ensuring the efficient functioning of an economic mechanism that stimulates innovative development and providing state support to industries that are strategically important for economic development and competitiveness of the national economy.

The various approaches to the role of the state in the economy at different stages of economic development were researched, to establish that it is necessary to perform certain functions in the economy of the country. However, there is a large discrepancy in the views of the limits and skills of state currents in the economy-from liberal to threshold state regulation of economic processes.

Conclusion. After analyzing the current trends of transformation processes, it has been found that for the effective development of the national economy in the 21st century, the strengthening of the role of the state in the economy should not be understood in the old sense as the establishment of a bureaucratic obstacle for entrepreneurship. The state, adjusting former mistakes of economic policy, has to take on the inherent functions of protecting the national economy from the adverse effects of globalization, stimulating innovation development, providing a rational, with a view to the future, the use of resources.

Keywords: state, state regulation of economy, market self-regulation, globalization, competitiveness. 


\section{REFERENCES}

1. Adzhemoglu, D., \& Robinson, Dzh. (2017). Chomu nacii' zanepadajut' [Why nations are declining]. Kyi'v: Nash format [in Ukrainian].

2. Akerlof, Dzh., \& Shyller, R. (2017). Hto i jak manipuljuje vashym vyborom [Who and how manipulates your choice]. (O. Gerasymchuk Trans). Kyiv: Nash format [in Ukrainian].

3. Gejec', V. (2015). Podolannja kvazirynkovosti - shljah do investycijno orijentovanoi' modeli ekonomichnogo zrostannja [Overcoming quasi-marketability is the path to an investment-oriented model of economic growth]. Ekonomika Ukrai'ny - Ukraine economy, 6, 4-17 [in Ukrainian].

4. Grycenko, A. (2017). Arhitektonika ekonomichnoi' bezpeky [Economic security architectonics]. Kyiv: NAN Ukrai'ny, In-t ekonomiky ta prognozuvannja NAN Ukrai'ny [in Ukrainian].

5. Zhalilo, Ja. (2016). Pro nacional'ni osoblyvosti ekonomichnogo pragmatyzmu [On the national features of economic pragmatism]. Dzerkalo tyzhnja-Mirror of the week, 49 [in Ukrainian].

6. Kindzers'kyj, Ju. (2015). Derzhavne zamovlennja u sviti ta osoblyvosti jogo zastosuvannja u polityci rozvytku: uroky dlja Ukrai'ny [State order in the world and features of its application in development policy: lessons for Ukraine]. Ekonomika Ukrai'ny - Ukraine economy, 3, 4-25 [in Ukrainian].

7. Lagutin, V. (2017). Ekonomichna polityka derzhavy ta efekty i'i' realizacii' [The economic policy of the state and the effects of its implementation]. Visnyk Kyi'v. nac. torg.-ekon. un-tuHerald of the Kyiv National University of Trade and Economics, 4, 5-20 [in Ukrainian].

8. Mazaraki, A., Melnichenko, S., \& Duginets, G. (2018). Ukrainian economy growth imperatives. Prague: Coretex CZ SE [in Ukrainian].

9. Soto, de E. (2017). Zagadka kapitalu. Chomu kapitalizm peremagaje na Zahodi i nide bil'she [Riddle of capital. Why capitalism wins in the West and nowhere else]. Kyiv: Nash format [in Ukrainian].

10. Umanciv, Ju., \& Minjajlo, O. (2016). Evoljucija roli ta funkcij derzhavy v ekonomici [Evolution of the role and functions of the state in the economy]. Ekonomichnyj visnyk universytetu - Economic Herald of the University, 28 (1), S. 140-148 [in Ukrainian].

11. Smit, A. (2001). Dobrobut nacij. Doslidzhennja pro pryrodu ta prychyny dobrobutu nacij [Welfare of nations. Research on the nature and causes of the well-being of nations]. (O. Vasyl'jeva, Trans). Kyiv: Port-Royal [in Ukrainian].

12. Mill', Dzh. S. (1980). Osnovy politicheskoj jekonomii [Fundamentals of political economy]. (A. G. Milejkovskogo, Trans). (Vols. 1-2). Moscow: Progress [in Russian].

13. Kejns, Dzh. M. (2011). Obshhaja teorija zanjatosti, procenta i deneg [The general theory of employment, interest and money]. (N. N. Ljubimova, Trans). Moscow: Gelios ARV [in Russian].

14. Marshall, A. (2010). Principy jekonomicheskoj nauki [Principles of economic science]. (Vols. 3). Moscow: Bizneskom [in Russian].

15. Gjelbrejt, Dzh. K. (2008). Novoe industrial'noe obshhestvo [A new industrial society]. Izbrannoe. Moscow: Jeksmo [in Russian].

16. Danylyshyn, B. (2016). Pro taktyku ekonomichnogo rozvytku [On the tactics of economic development]. Livyj bereg - Left Bank. 16.12.2016. Retrieved from http://blogs.lb.ua/bogdan_danylysyn/353627 [in Ukrainian].

17. Panchenko, V. (2016). Operacija «deindustrializacija», abo navishho nam promyslovyj renesans [Operation «de-industrialization», or why we need an industrial renaissance]. Dzerkalo tyzhnja-Mirror of the week, 9 [in Ukrainian].

18. The World Competitiveness Yearbook 2019. International Institute for Management Development. Lausanne, Switzerland. Retrieved from https://www.imd.org/wcc/ products/eshop-world-competitiveness-yearbook [in English].

19. Art'omova, T. (2016). Vidnosyny suspil'nogo vidtvorennja v Ukrai'ni u konteksti transformacii' modelej derzhavnogo upravlinnja [Relations of social reproduction in Ukraine in the context of transformation of governance models]. Ekonomichna teorijaEconomic theory, 3, 5-17 [in Ukrainian]. 